\title{
Minimalisasi Tingkat Plagiat Karya Ilmiah Mahasiswa Melalui Workshop Software Plagiarism Checker X
}

\author{
Syaharuddin ${ }^{1)}$, Vera Mandailina ${ }^{2)}$, Saddam $^{3)}$, Habib Ratu Perwira Negara ${ }^{4}$, \\ Malik Ibrahim ${ }^{5)}$, Rody Satriawan') \\ Universitas Muhammadiyah Mataram ${ }^{1), 2), 3), 4)}$ \\ Teknik Informatika, Universitas Bumigora Mataram ${ }^{5)}$ \\ Universitas Hamzanwadi ${ }^{6)}$ \\ Email: syaharuddin.ntb@gmail.com ${ }^{1}$
}

\begin{tabular}{|l|l|l} 
Dikirim: 09-01-2021 & Direvisi: 12-02-2021 & Diterbitkan: 28-02-2021
\end{tabular}

\begin{abstract}
Abstrak
Salah satu upaya untuk minimalisasi tingkat plagiat di kalangan mahasiswa dalam menyusun tugas akhir adalah optimalisasi studi literatur dan melakukan pengecekan tingkat plagiat menggunakan aplikasi standar seperti Plagiarism CheckerX. Tujuan kegiatan ini adalah meningkatkan kemampuan mahasiswa dalam menyusun tugas akhir dengan tingkat plagiasi tidak lebih dari 30\%. Oleh sebab itu, sebanyak 83 mahasiswa telah mengikuti kegiatan workshop penggunaan software Plagiarism CheckerX serta dijelaskan teknik memperbaiki hasil plagiat jika lebih dari 30\%. Angket merupakan alat evaluasi yang digunakan dalam kegiatan ini. Hasil pelaksanaan kegiatan menunjukkan bahwa sebesar $89 \%$ mahasiswa memahami materi yang disampaikan dan memahami teknik mengecek plagiat serta memperbaiki hasil plagiat tersebut.
\end{abstract}

Kata Kunci: cek plagiat; karya ilmiah; plagiarsm checkerx.

\begin{abstract}
One of the efforts to minimize the level of plagiarism among students in preparing the final task is optimization of literature studies and checking the level of plagiarism using standard applications such as Plagiarism CheckerX. The purpose of this activity is to improve students' ability to arrange final assignments with a plagiarization rate of no more than 30\%. Therefore, as many as 83 students have participated in workshops on the use of Plagiarism CheckerX software and described techniques to improve the results of plagiarism if more than 30\%. Questionnaire is an evaluation tool used in this activity. The results of the activities showed that $89 \%$ of students understood the material presented and understood the technique of checking plagiarism and improving the results of plagiarism.
\end{abstract}

Keywords: check plagiarism; scientific work; plagiarism checkerx.

\section{PENDAHULUAN}

Tindakan plagiasi merupakan tindakan yang tidak terpuji ketika memulai penelitian hingga menyusun dan menyelesaikansebuah karya ilmiah(Mulyana et al., 2015). Oleh sebab itu, pemerintah, dosen pembimbing, bahkan pengelola jurnal selalu berhati-hati dalam menerima dan memeriksa sebuah karya ilmiah(Algaelovia, 2013). Pemerintah mengeluarkan kebijakan bahwa setiap karya ilmiah yang diupload ke repository kampus harus melalui cek plagiasi(Kurniawan, 2016), (Hadna, 2014). Sedangkan dosen pembimbing tugas akhir baik skripsi, tesis, maupun disertasi mewajibkan mahasiswa untuk melakukan cek plagiasi ketika akan mengikuti seminar hasil. Terakhir, pengelola jurnal selalu mengecek paper atau makalah 
yang masuk ke meja redaksi untuk menghindari tindakan plagiat tersebut, salah satunya dengan menetapkan interval maksimal dari hasil cek plagiat paper tersebut.

Namun fakta di lapangan tindakan plagiat masih marak dilakukan, khususnya di kalangan mahasiswa. Hal ini dilakukan umumnya karena beberapa factor, diantaranya (1) minimnya jiwa literasi mahasiswa untuk membaca banyak referensi atau artikel-artikel yang sudah terbit secara online, (2) terbatasnya aplikasi cek plagiat yang murah dan terjangkau, karena harus membayar langganan dan lisensi, (3) mahasiswa belum memahami prosedur cek plagiat dan cara memperbaikinya, (4) banyak beredar hasil-hasil penelitian berupa skripsi, tesis, bahkan disertasi yang belum terunggah ke repository ataupun publish di jurnal secara online(Hakim, 2018), (Santoso, 2015), (Wibowo, 2012).

Lebih lanjut Silvana et al., (2018) dalam penelitiannya menjelaskan bahwa faktorfaktor penyebab tindakan plagiarisme disebabkan karena (1) minimnya pengetahuan mengenai gaya selingkung penulisan, (2) ketersediaan waktu yang terbatas dalam penyusunan tugas akhir mahasiswa, (3) perkembangan teknologi informasi (khususnya internet) yang memudahkan dan membuka peluang berbuat curang, (4) sebagian dosen belum protektif pada isu plagiarisme, (5) penggunaan aplikasi anti plagiarisme masih minim, (6) juga sosialisasi mengenai isu plagiarisme yang masih belum mencukupi kebutuhan informasi yang perlu diketahui oleh mahasiswa. Sedangkan hasil penelitian Arista \& Listyani (2015) menjelaskan bahwa faktor penyebabnya yakni (1) karena budaya dosen dalam mengajar, (2) akses informasi yang mudah, (3) minimnya pengetahuan tentang plagiarisme, (4) minimnya pengawasan, (5) orientasi nilai dan IPK, serta (6) faktor ekonomi.

Oleh sebab itu, banyaknya motif tersebut membuat tindakan plagiarisme di Indonesia masih banyak. Maka dari itu banyak dikembangkan aplikasi pendeteksi plagiat mahasiswa, misalnya penelitian tentang semantic similarity pada artikel web (Kowanda et al., 2014), aplikasi Journal Information System Management(Mandailina et al., 2017), pengembangan Algoritma Rabin-Karp (Putra \& Sujaini, 2015), aplikasi DASS (Syaharuddin et al., 2019), serta tindakan atau pelatihan-pelatihan kepada mahasiswa untuk mencegah atau mengurangi tindakan plagiat (Farhat, 2019), (Wibowo, 2012), mengajukan hak cipta setiap karya ilmiah (Hakim, 2018). Selanjutnya Sulistyaningsih (2017) memberikan rekomendasi dalam pencegahan tindakan plagiarisme yakni (1) menumbuhkan rasa integritas dan rasa malu memplagiat dalam diri akademisi; (2) meningkatkan fungsi dan peranan pembimbing penelitian; (3) memberikan sanksi yang jelas dan tegas terhadap pelaku plagiarism; (4) membangun bank data jurnal di setiap lembaga penelitian; (5) menggunakan software anti plagiarism.

Saat ini sudah ada software standar yang bisa digunakan untuk mengecek plagiat seperti Turnitin, Ithenticate, Wcopyfind, Viper, Plagiarism CheckerX, Gramarly, dan sebagainya. Dari banyaknya software pengecek plagiat tersebut banyak yang bersifat langganan sehingga sulit dijangkau oleh mahasiswa. Sehingga software PlagiarismCheckerX menjadi tumpuan yang cukup banyak diminati karena masih terjangkau.

Pentingnya kegiatan ini merupakan wujud dari optimalisasi publikasi karya ilmiah secara online dan dapat dipertanggungjawabkan. Sehingga hasil-hasil penelitian yang dilakukan merupakan hasil kerja nyata secara ilmiah yang dilakukan oleh mahasiswa yang terbimbing. Dari permasalahan dan tawaran solusi tersebut, maka tujuan yang ingin dicapai dari kegiatan ini adalah (1) mahasiswa memiliki aplikasi atau software cek plagiat secara gratis namun tetap berlisensi, (2) mahasiswa mampu menggunakan softwarePlagiarsm CheckerX untuk mengecek plagiat dari proposal skripsi masing-masing, (3) mengurangi tingkat persentase hasil plagiat proposal skripsi mahasiswa.

\section{METODE}


Kegiatan ini dilaksanakan selama tiga hari di Fakultas Keguruan dan Ilmu Pendidikan UM Mataram dengan jumlah mahasiswa tiap klaster sebanyak 27-28 orang, jadi total keseluruhan sebanyak 83 orang. Bentuk kegiatan adalah workshop dimana mahasiswa langsung praktik di laptop masing-masing untuk melakukan cek plagiat dan memperbaikinya. Adapun tahapan pelaksanaan sebagai berikut.

1. Pemateri bersama dua orang instruktur menyampaikan materi tentang (a) kebijakan pemerintah dalam hal plagiasi; (2) pentingnya melakukan cek plagiat sejak dari awal proposal; (3) cara memperbaiki hasil cek plagiat jika akumulasi lebih dari $30 \%$.

2. Mahasiswa melakukan instalasi software Plagiarism CheckerX dari folder yan sudah dibagikan sebelumnya oleh instruktur.

3. Mahasiswa dibawah bimbingan instruktur melakukan cek plagiat terhadap proposal skripsi masing-masing, kemudian didiskusikan bersama instruktur untuk proses perbaikan atau paraprase tiap kalimat yang terdeteksi tindakan plagiasi.

4. Mahasiswa melakukan pengecekan kembali melalui software Plagiarism CheckerX setelah melakukan proses perbaikan atau paraphrase. Hal ini secara terus dilakukan sampai hasil cek plagiat di bawah $30 \%$.

5. Pemateri atau instruktur melakukan evaluasi kegiatan. Kegiatan evaluasi dilakukan secara dua metode yakni observasi dan penilaian melalui angket. Metode observasi dilakukan ketika kegiatan praktik berlangsung sehingga pemateri dan instruktur bias melihat keberhasilan dan kekurangan para peserta. Sedangkan angket yang berisi 5 pertanyaan inti sebarkan via WA Group pasca kegiatan berlangsung. Adapun indikator yang menjadi pertanyaan yakni (1) software Plagiarism CheckerX bermanfaat bagi mahasiswa dalam mengurangi tingkat plagiat; (2) pengetahuan tentang publikasi di jurnal ilmiah bermanfaat bagi mahasiswa; (3) tingkat penguasaan mahasiswa dalam menggunakan software Plagiarism CheckerX; (4) kendala-kendala yang mahasiswa alami saat workshop; (5) hasil cek plagiat proposal berada pada interval tertentu. Adapun link kuosioner dapat dilihat dihttp://bit.ly/3q2TZDe.

\section{HASIL DAN PEMBAHASAN}

\section{Pentingnya Cek Plagiat dan Kebijakan Pemerintah}

Peraturan tentang cek plagiat sudah disampaikan oleh pemerintah khususnya Dirjen Dikti RI melalui Surat No 1311/D/C/2010 tentang pencegahan dan penanggulangan plagiat hal ini juga diperkuat dengan Surat yang diterbitkan LLDikti IX No 7183/LL9/EP/2020. Sehingga di level Dosen sudah banyak yang menerapkannya. Setidaknya ada beberapa sanksi jika terdeteksi sebagai hasil plagiat yakni (1) teguran, (2) peringatan; (3) penundaan pemberian sebagian hak mahasiswa; (4) pembatalan nilai salah satu atau beberapa mata kuliah yang diperoleh mahasiswa; (5) pemberhentian dengan hormat dari status sebagai mahasiswa; (6) pemberhentian dengan tidak hormat dari status sebagai mahasiswa; (7) pembatalan ijazah apabila mahasiswa telah lulus dari suatu program. Hasil observasi menunjukkan tingginya antusias mahasiswa dalam memperhatikan, menerima dan memahami materi yang disampaikan. Diskusipun dilakukan sambil penyampaian materi sehingga timbal balik dari materi yang disampaikan dapat dipahami oleh mahasiswa dengan baik.

\section{Instalasi Software Plagiarishm CheckerX}

Setelah materi disampaikan dengan baik, dilanjutkan dengan praktik instalasi software PlagiarsmCheckerX oleh mahasiswa di masing-masing laptopnya. Gambar 1 menunjukkan bahwa proses instalasi berjalan dengan lancar meskipun masi terdapat kendala sederhana 
seperti sinyal yang tidak kuat karena pemakaian jaringan dalam jumlah besar secara bersamaan.

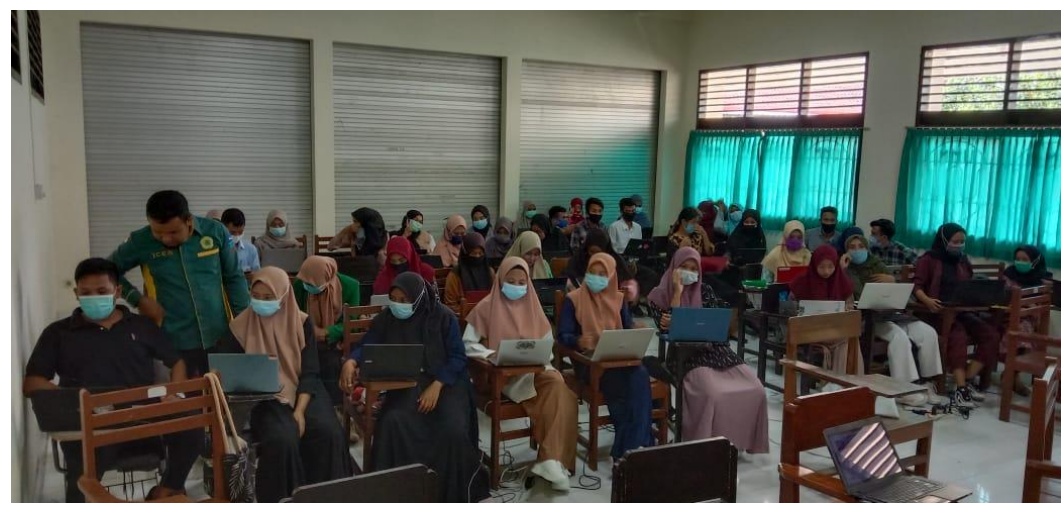

Gambar 1: Proses Instalasi Plagiarism CheckerX

\section{Hasil Cek Plagiat}

Hasil cek plagiat merupakan laporan atau output yang keluarkan oleh software Plagiarsm CheckerX dengan cara mengkomulatifkan setiap hasil cek plagiat perkalimat atau perparagraf. Sebelum melakukan upload file proposal skripsi ke system Plagiarism CheckerX mahasiswa diminta untuk menyatukan file dari Bab 1 sampai Daftar Pustaka dalam satu file type word. Selanjutnya diupload ke system dan dijalankan untuk melihat letak kalimat atau paragraph yang dianggap hasil plagiat.Adapun hasil cek plagiat proposal skripsi sesuai Tabel 1 berikut.

Tabel1:Rata-rata Hasil Cek Plagiat

\begin{tabular}{clr}
\hline No & \multicolumn{1}{c}{ Interval } & Jumlah Proposal \\
\hline 1 & Kurang 20\% & 7 \\
\hline 2 & $21 \%-30 \%$ & 17 \\
\hline 3 & $31 \%-40 \%$ & 26 \\
\hline 4 & $41 \%-100 \%$ & 21 \\
\hline 5 & Belum Cek Plagat & 12 \\
\hline \multicolumn{2}{c}{ Jumlah } & 83 \\
\hline
\end{tabular}

Tabel 1 menunjukkan bahwa hasil plagiat proposal mahasiswa paling banyak berada pada interval $31 \%-40 \%$ sebanyak 26 proposal, sedangkan paling rendah pada interval kurang dari $20 \%$ sebanyak 7 proposal.

\section{Hasil Evaluasi Kegiatan}

Evaluasi kegiatan dilakukan menggunakan dua teknik yakni teknik observasi dan teknik angket.Hasil observasi menunjukkan bahwa hampir 98\% mahasiswa telah berhasil menginstal software Plagiarism CheckerX. Sedangkan menurut hasil angket menunjukkan bahwa secara keseluruhan rata-rata sebesar $89 \%$ mahasiswa sudah memahami materi dan proses cek plagiat dan mampu melakukan paraphrase hasil cek plagiat proposal skripsinya, hal ini sesuai Tabel 2 berikut.

Tabel2:Hasil Evaluasi Kegiatan

\begin{tabular}{clrccc}
\hline & & \multicolumn{4}{c}{ Item Penilaian } \\
\hline No & Program Studi & $\mathbf{1}$ & $\mathbf{2}$ & $\mathbf{3}$ & $\mathbf{4}$ \\
\hline 1 & Bahasa Indonesia & 96.8 & 93.7 & 84.2 & 81.1 \\
\hline 2 & Bahasa Inggris & 93.3 & 95.6 & 93.3 & 77.8 \\
\hline 3 & Fisika & 100.0 & 95.0 & 90.0 & 85.0 \\
\hline
\end{tabular}




\begin{tabular}{rlrrrr}
\hline 4 & Matematika & 100.0 & 93.3 & 86.7 & 80.0 \\
\hline 5 & Geografi & 100.0 & 98.2 & 87.3 & 92.7 \\
\hline 6 & PPKn & 93.3 & 90.0 & 66.7 & 56.7 \\
\hline 7 & PGSD & 94.5 & 97.2 & 89.0 & 81.4 \\
\hline & Rata-rata & $\mathbf{9 6 . 9}$ & $\mathbf{9 4 . 7}$ & $\mathbf{8 5 . 3}$ & $\mathbf{7 9 . 2}$ \\
\hline
\end{tabular}

Dari Tabel 2 juga dapat diketahui bahwa mahasiswa dari Program Studi Geografi memiliki tingkat pemahaman terhadap materi dan praktik cek plagiat hampir sempurna yakni sebesar $94,5 \%$. Sedangkan program studi paling rendah tingkat pemahamannya yakni PPKn sebesar $76,7 \%$.

Dari hasil kegiatan yang telah dilakukan terdapat beberapa kendala secara teknis yakni jaringan internet yang kurang mendukung sehingga kecepatan koneksi tidak optimal, laptop tiba-tiba error yang tidak bisa melanjutkan kegiatan instalasi.Solusi dari permasalahan ini tidak bisa dilakukan secara langsung, perlu dilakukan perbaikan secara bertahap untuk kegiatan-kegiatan berikutnya terutama yang berkaitan dengan jaringan internet, namun sebagai solusi sementara yakni jaringan internet dialihkan ke jaringan hotspot smartphone masing-masing mahasiswa sehingga tidak terpusat ke jaringan wifi kampus.

Pasca kegiatan mahasiswa secara aktif melakukan perbaikan pada proposal masingmasing dengan cara paraphrase setiap kalimat yang terdeteksi sebagai hasil plagiat. Hal ini untuk menghindari tingkat persentase plagiat yang terlalu tinggi. Selain itu, tindakan paraphrase ini dapat meningkatkan perbendaharaan kalimat mahasiswa, tentu hal ini akan menjadi referensi baru bagi mahasiswa dalam menyelesaikan tugas akhirnya.

\section{SIMPULAN}

Dari kegiatan ini mahasiswa sudah berhasil menginstal software Plagiarism CheckerX dengan baik serta mengoperasikannya untuk mengecek hasil plagiat pada proposal masingmasing.Dari pengecekan ini rata-rata hasilnya berada pada interval 31\%-40\%. Tindakan paraphrase dilakukan dalam rangka memperbaiki dan mengurangi tingkat persentase plagiat tersebut. Hasil akhir, mahasiswa rata-rata $89 \%$ sudah memahami materi dan praktik dari yang disampaikan oleh pemateri dan instruktur.Dari kegiatan ini, tim penulis menyarankan mahasiswa tetap melakukan cek plagiat pada skripsi sebelum melakukan ujian skripsi nantinya, termasuk juga pasca ujian skripsi ketika membuat artikel ilmiah dengan standar hasil plagiat maksimal 20\%. Sehinga memudahkan pada saat akan submit untuk publikasi ke sebuah jurnal.

\section{UCAPAN TERIMA KASIH}

Tim penulis mengucapkan Terima Kasih kepada Pimpinan Fakultas Keguruan dan Ilmu Pendidikan, UM Matarm yang telah memberikan ijin dan support sehingga kegiatan ini berjalan dengan lancar. Selanjutnya, kepada mahasiswa yang sudah antusias mengikuti kegiatan ini. Semoga dapat diterapkan secara maksimal dalam rangka mengurangi tingkat plagiat pada hasil karya ilmiahnya.

\section{DAFTAR PUSTAKA}

Al Musthafa, S., Abdillah, A., AK, K. R., Mandailina, V., Pramita, D., \& P.N, H. R. (2019). DASS Application: Increasing the Quality of Academic Services for Lecturers and Students. International Journal of Scientific Research and Management, 7(01). https://doi.org/10.18535/ijsrm/v7i1.ec03 
Algaelovia. (2013). Definisi, Jenis, dan Contoh Kasus Plagiarisme. In 19 November.

Arista, R. F., \& Listyani, R. H. (2015). Plagiarisme di Kalangan Mahasiswa. In Paradigma (Vol. 3, Issue 2).

Farhat, L. (2019). Upaya Pencegahan Tindakan Plagiarisme untuk Meningkatkan Kualitas Penulisan Karya Tulis Ilmiah di Dalam Pembimbingan Tugas Akhir (Skripsi) Bagi Mahasiswa STIE Jambi. J-MAS (Jurnal Manajemen Dan Sains), 4(2), 326. https://doi.org/10.33087/jmas.v4i2.114

Hadna, I. N. (2014). Peran Perpustakaan Dalam Mengembangkan Institutional Repository di UIN Sunan Kalijaga Yogyakarta. Pustakaloka, 6(1), 13-22.

Hakim, G. (2018). Perlindungan Hukum Pencipta yang Dirugikan Haknya atas Tindakan Plagiarisme. Halu Oleo Law Review, 2(1), 416. https://doi.org/10.33561/holrev.v2i1.4199

Kowanda, A., Siregar, I. P., Lie, J., Irmawati, N. F., \& Purnamasari, D. (2014). Pengukur semantic similarity pada artikel web dalam upaya pencegahan plagiarisme. Kommit, 8(Kommit), 33-40.

Kurniawan, T. (2016). Peran Perpustakaan Perguruan Tinggi Dalam Mengembangkan Repositori Institusi. Pustakaloka, 8(2), 231-243.

Mandailina, V., Pn, H. R., \& Ak, K. R. (2017). JISYM : Desktop Application to Increase Lecturer Publication Ratio. International Journal of Innovative Science, Engineering \& Technology, 4(11), 197-201.

Mulyana, I., Chairunnas, A., \& Maesya, A. (2015). Identifikasi Plagiasi Karya Ilmiah berbasis Temu Kembali Informasi Menggunakan Algoritam Edit Distance Melalui Peringkasan Teks Otomatis. Jurnal Senatek, 1(1), 866-874.

Putra, D. A., \& Sujaini, H. (2015). Implementasi Algoritma Rabin-Karp untuk Membantu Pendeteksian Plagiat pada Karya Ilmiah. Jurnal Sistem Dan Teknologi Informasi (JUSTIN), 4(1), 66-74.

Santoso, H. (2015). Pencegahan Dan Penaggulangan Plagiarisme Dalam Penulisan Karya Ilmiah Di Lingkungan Perpustakaan Perguruan Tinggi. Univesitas Negeri Malang, 1, 123.

Silvana, H., Rullyana, G., \& Hadiapurwa, A. (2018). Persepsi Mahasiswa Terhadap Tindakan Plagiarisme Dalam Penyusunan Tugas Akhir. Edutech, 16(3), 338. https://doi.org/10.17509/e.v16i3.8508

Sulistyaningsih, L. (2017). Plagiarisme, Upaya Pencegahan, Penanggulangan dan Solusinya. Jurnal Pustaka Ilmiah, 3(1), 320-328.

Wibowo, A. (2012). Mencegah dan Menanggulangi Plagiarisme di Dunia Pendidikan. Kesmas: National Public Health Journal, 6(5), 195. https://doi.org/10.21109/kesmas.v6i5.84 